\title{
Pelatihan Higiene dan Sanitasi Makanan pada Pedagang Makanan di Kantin Sekolah Dasar
}

\author{
Jamilatur Rohmah ${ }^{1}$, Siti Cholifah ${ }^{2}$, Vanda Rezania ${ }^{3}$ \\ ${ }^{1}$ Teknologi Laboratorium Medis. Universitas Muhammadiyah Sidoarjo, \\ ${ }^{2}$ Kebidanan. Universitas Muhammadiyah Sidoarjo, ${ }^{3}$ Pendidikan Guru Sekolah Dasar. Universitas Muhammadiyah \\ Sidoarjo. \\ jamilaturrohmah@umsida.ac.id¹, cholifah_siti79@yahoo.com², vandarezania@umsida.ac.id ${ }^{3}$
}

\begin{abstract}
The school canteen has an important role to fulfill the food needs of school children. The need for fulfillment of hygienic foods is ordered by the factors of place and hygiene of the food handlers. Foods that do not meet the requirements and safety that can be given due to health problems or diseases related to food such as diarrhea, cholera, dysentery, typhus, and other food poisoning. The number of food handlers in the cafeteria of SD Muhammadiyah 1 and 2 Sidoarjo competes 6 people. Based on the results of observations and interviews, they did not have sufficient educational background and never gained knowledge about food hygiene and sanitation. The purpose of this program are to improve the knowledge, attitudes, and behavior of food handlers about food hygiene and sanitation so not to harm their consumers health, especially school children. The method used is a training and mentoring model for food handlers starting when preparing food, processing, and serving to customers. The results of these program can be known about changes in the knowledge and skills of food handlers in food hygiene and sanitation.
\end{abstract}

Keywords: food hygiene and sanitation; food handlers; training and mentoring; elementary school canteens.

\begin{abstract}
Abstrak
Kantin sekolah mempunyai peranan penting untuk memenuhi kebutuhan makanan jajanan anak sekolah. Sehingga pemenuhan kebutuhan akan makanan jajanan yang higienis dipengaruhi oleh faktor sanitasi tempat dan higiene pedagang makanan perlu untuk dilakukan. Makanan yang tidak memenuhi persyaratan mutu dan keamanan diantaranya dapat menimbulkan gangguan kesehatan atau penyakit bawaan makanan seperti diare, cholera, disentri, typhus, dan keracunan makanan lainnya. Jumlah pedagang makanan di kantin SD Muhammadiyah 1 dan 2 Sidoarjo berjumlah 6 orang. Berdasarkan hasil observasi dan wawancara, umumnya mereka tidak memiliki latar belakang pendidikan yang cukup dalam hal higiene dan sanitasi makanan, serta mereka tidak pernah mendapatkan pengetahuan mengenai higiene dan sanitasi makanan. Dengan adanya hal tersebut maka tujuan dari kegiatan pelatihan ini adalah untuk meningkatkan pengetahuan, sikap, dan perilaku pedagang tentang higiene dan sanitasi makanan sehingga tidak membahayakan kesehatan konsumennya terutama anak sekolah. Metode yang digunakan dengan model pelatihan dan pendampingan kepada para pedagang mulai saat mempersiapkan bahan makanan, pengolahan, sampai dengan penyajian ke konsumen. Hasil yang diperoleh dari dilakukannya program ini adalah dapat diketahui adanya perubahan pengetahuan dan
\end{abstract}


keterampilan para pedagang dalam hal hygiene dan sanitasi makanan.

Kata kunci: higiene dan sanitasi makanan; pedagang makanan; pelatihan dan pendampingan; kantin SD.

\section{A. PENDAHULUAN}

Kantin sekolah merupakan tempat yang mempunyai peranan penting untuk memenuhi kebutuhan makanan jajanan anak sekolah. Makanan jajanan yang dijual di kantin sekolah pada umumnya mempunyai variasi yang sangat beragam, dengan harga yang relatif murah, dan mudah dijangkau oleh anak sekolah. Sehingga pemenuhan kebutuhan akan makanan jajanan yang higienis dipengaruhi oleh faktor sanitasi tempat dan higiene pedagang makanan perlu untuk dilakukan. Karena yang secara langsung berhubungan dengan makanan dan peralatan mulai dari tahap persiapan, pembersihan, pengolahan, pengangkutan sampai penyajian adalah pedagang makanan (Depkes RI, 2006; Ramli, 2018).

Hygiene dan sanitasi makanan merupakan pengendalian terhadap 4 faktor, yaitu faktor tempat, bahan makanan, peralatan, dan orang (penjamah makanan/ pedagang). Sedangkan sanitasi makanan merupakan salah satu usaha pencegahan yang menitikberatkan pada kegiatan dan tindakan yang perlu untuk membebaskan makanan dan minuman dari segala bahaya yang dapat mengganggu kesehatan, mulai dari sebelum makanan diproduksi, selama dalam proses pengolahan, penyimpanan, pengangkutan, sampai pada saat dimana makanan dan minuman tersebut siap untuk dikonsumsikan kepada masyarakat atau konsumen. Dalam hal ini kantin sekolah dengan konsumennya sebagian besar adalah anak-anak (Prabu, 2018; Depkes RI, 2006).

Hal serupa terjadi di Desa/Kelurahan Pucang Anom dan Lemahputro Sidoarjo karena disini terdapat Sekolah Dasar Muhammadiyah 1 \& 2 dan jumlah penduduknya yang cukup padat. Selain itu SD Muhammadiyah 2 lokasinya berdekatan dengan pasar tradisional. Jumlah pedagang makanan di kantin SD Muhammadiyah 1 dan 2 Sidoarjo berjumlah 6 orang. Dalam hal higiene dan sanitasi makanan, pada umumnya mereka tidak memiliki latar belakang pendidikan yang cukup. Hal ini tentu akan sangat mempengaruhi kualitas makanan yang disajikan kepada konsumen khususnya anak sekolah.

Berdasarkan hasil observasi dan wawancara kepada beberapa pedagang, mereka mengatakan tidak pernah mendapatkan pengetahuan khusus mengenai higiene dan sanitasi makanan, tidak pernah berusaha untuk membaca buku mengenai sanitasi makanan, serta tidak pernah mendapatkan pelatihan yang berhubungan dengan higiene dan sanitasi makanan. Hal ini terlihat saat melayani pembeli (muridmurid) mereka tidak memperhatikan kebersihan, seperti tidak mencuci tangan saat mengambil makanan setelah sebelumnya melakukan kegiatan lain seperti mengambil uang, menggaruk kaki, dll. Hal ini akan sangat mempengaruhi kualitas makanan yang disajikan kepada konsumen khususnya anak SD. Karena makanan yang tidak memenuhi keamanan dan persyaratan mutu diantaranya dapat menimbulkan gangguan kesehatan atau penyakit bawaan makanan seperti disentri, diare, typhus, cholera, dan keracunan makanan lainnya (WHO, 2005; Adam, 2003).

Tindakan preventif dinilai sangat penting meskipun memang belum terdapat 
kasus keracunan yang disebabkan oleh makanan jajanan produksi kantin tersebut. Tindakan ini dimaksudkan untuk mencegah faktor risiko yang bisa saja muncul akibat higiene dan sanitasi yang kurang agar makanan jajanan kantin aman dikonsumsi dan mencegah kejadian penyakit bawaan makanan maupun keracunan yang disebabkan oleh makanan karena apabila makanan terkontaminasi oleh zat-zat yang berbahaya maka kasus keracunan makanan tidak dapat dihindari (Hartono, 2002; Winarno, 2004).

Berdasarkan hal tersebut maka metode pendekatan yang ditawarkan dalam program ini adalah model pelatihan dan pendampingan mitra (para pedagang makanan di kantin) tentang hygiene dan sanitasi makanan mulai pemilihan bahan, pengolahan, sampai dengan penyajian ke konsumen.

\section{B. PELAKSAAAN DAN METODE}

Kegiatan pelatihan hygiene dan sanitasi makanan di kantin SD dilaksanakan selama 4 bulan. Jumlah para pedagang makanan di kantin SD Muhammadiyah 1 dan 2 Sidoarjo sebanyak 6 orang dengan latar belakang pendidikan yang kurang dalam hal higiene dan sanitasi makanan. Mekanisme pelaksanaan pelatihan ini adalah sebagai berikut:

\section{Persiapan Pelatihan}

Sebelum kegiatan pelatihan higiene dan sanitasi makanan dilakukan pada para pedagang makanan di kantin SD Muhammadiyah 1 \& 2 Sidoarjo, terlebih dahulu tim pengusul mempersiapkan materi pelatihan. Kegiatan pelatihan dalam bentuk pendampingan dilaksanakan di rumah dan di sekolah tempat para pedagang berjualan. Selain itu juga akan dilakukan forum diskusi yang akan dilaksanakan di aula sekolah bersama mitra, dan bekerjasama dengan kepala sekolah dan guru-guru SD Muhammadiyah 1 \& 2 Sidoarjo. Rencana implementasi kegiatan pendampingan tersebut mencakup:

a. Mempersiapkan form penilaian hygiene dan sanitasi.

Sedangkan untuk forum diskusi, rencana implementasinya yaitu:

a. Mempersiapkan materi atau powerpoint untuk pelatihan ke mitra.

b. Mempersiapkan pelatihan kit yang meliputi materi pelatihan, modul higiene dan sanitasi, ATK, dan blocknote.

c. Pembagaian tugas tim pelaksana untuk diskusi dan tanya jawab.

d. Mempersiapkan umpan balik pelatihan dalam bentuk kuisioner.

\section{Pelaksanaan Pelatihan Higiene dan Sanitasi}

Pelatihan ini dilakukan dengan melakukan pendampingan ke rumah dan sekolah tempat para pedagang berjualan. Tim pelaksana membawa format penilaian yang berhubungan dengan higiene dan sanitasi makanan yang digunakan untuk menilai selama proses pendampingan. Pendampingan ini dilakukan dua kali di rumah dan dua kali di sekolah kepada masing masing pedagang. Pada saat pendampingan di rumah yang pertama pelaksana mengamati cara pengolahan makanan yang biasa dibuat oleh pedagang untuk dijual di sekolah. Selama proses pengolahan pelaksana memberi penilaian berdasarkan formulir yang telah disiapkan. Selain proses pengolahan tim juga menilai perlengkapan dapur pedagang seperti tersedianya tempat pembuangan sampah, 
air bersih, adanya binatang pengganggu seperti tikus dan kecoa. Setelah selesai pengamatan, tim memberikan penjelasan mengenai higiene dan sanitasi makanan kepada peserta dengan tujuan adanya peningkatan pengetahuan dan keterampilan mengenai higiene dan sanitasi makanan. Selanjutnya akan dilakukan pendampingan kedua satu minggu berikutnya untuk mengamati dan menilai proses pengolahan makanan serta kebersihan lingkungan dapur. Sedangkan pendampingan di sekolah dilakukan guna mengamati dan menilai cara pedagang menyajikan makanan kepada konsumennya (anak SD). Pendampingan juga dilakukan dua kali, yang pertama tim melakukan pengamatan dan penilaian kemudian memberikan penjelasan mengenai hal yang berhubungan dengan kebersihan penyajian makanan serta dampak negatifnya dan dilanjutkan pendampingan yang kedua satu minggu berikutnya.

\section{C.HASIL DAN PEMBAHASAN}

Kegiatan program pengabdian masyarakat dengan pelatihan higiene dan sanitasi kepada pedagang makanan dikantin SD memberikan manfaat yang besar. Para pedagang makanan bersemangat mengikuti kegiatan ini sebagai bentuk untuk meningkatkan pengetahuan, sikap, dan perilaku mereka dalam hal higiene dan sanitasi makanan. Berdasarkan permasalahan yang dihadapi oleh mitra (pedagang makanan di kantin SD Muhammadiyah 1 dan 2 Sidoarjo) maka kegiatan program pengabdian masyarakat dilaksanakan dalam bentuk pelatihan dengan melakukan pendampingan. Pendampingan yang dilakukan dilaksanakan di rumah pedagang dan di kantin sekolah tempat para pedagang berjualan selama bulan Januari sampai April 2019.

Selama proses pendampingan, tim pelaksana membawa form penilaian tentang hygiene dan sanitasi makanan yang digunakan untuk menilai kondisi hygiene dan sanitasi makanan para pedagang. Tim pelaksana pada saat pendampingan di rumah yang pertama, melakukan pengamatan cara pengolahan makanan yang biasa dilakukan oleh pedagang (Gambar 1). Serta melakukan penilaian berdasarkan form penilaian yang telah disiapkan. Selain proses pengolahan tim juga menilai perlengkapan dapur pedagang seperti tersedianya tempat pembuangan sampah, air bersih, adanya binatang pengganggu seperti tikus dan kecoa. Setelah selesai pengamatan, tim memberikan penjelasan mengenai higiene dan sanitasi makanan kepada peserta dengan tujuan adanya peningkatan pengetahuan dan keterampilan mengenai higiene dan sanitasi makanan. Serta memberikan penjelasan dampak negatif penggunaan bahan makanan yang kurang baik dan pengolahan makanan yang kurang bersih.

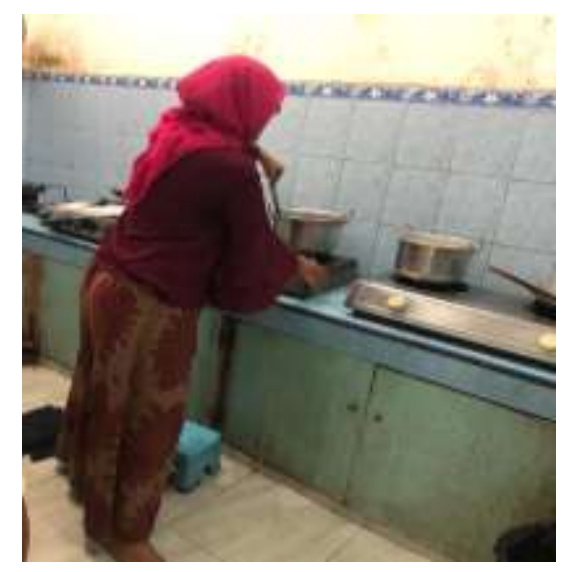

Gambar 1. Pendampingan di rumah

Kemudian dilakukan pendampingan di sekolah guna mengamati dan menilai cara pedagang menyajikan makanan kepada konsumennya (anak SD) seperti yang 
terlihat pada Gambar 2. Saat pengamatan di sekolah, ditemukan beberapa sikap dan perilaku yang kurang hygiene seperti tidak mencuci tangan setelah memegang uang dan tidak menggunakan sarung tangan plastik saat bersentuhan dengan makanan serta masih terdapat pedagang yang tidak menggunakan apron/celemek pada saat berjualan di kantin.

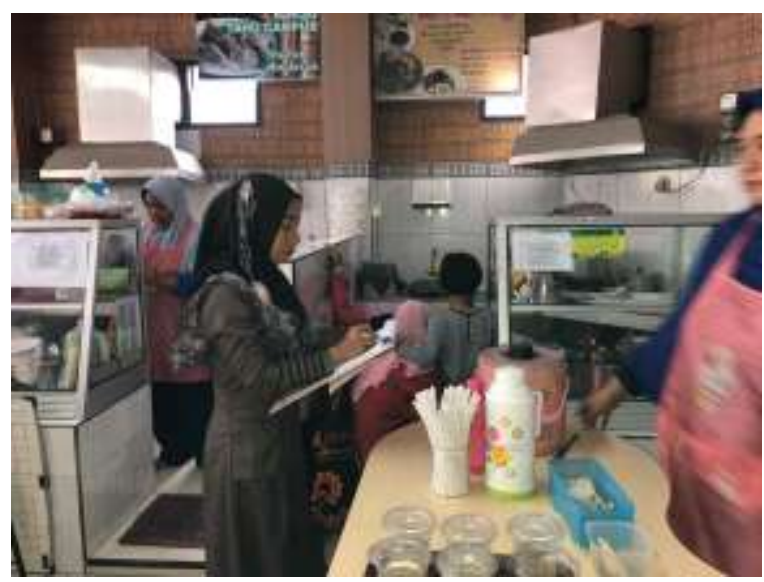

Gambar 2. Pendampingan di kantin sekolah

Kegiatan pelatihan selain dilakukan dalam bentuk pendampingan di rumah dan di sekolah, juga dilakukan dengan mengumpulkan seluruh pedagang dalam satu ruangan. Tujuannya adalah untuk melakukan diskusi mengenai pelaksanaan, hambatan dan kesulitan dalam hygiene dan sanitasi (Gambar 3). Dalam forum diskusi ini, disampaikan hambatan-hambatan maupun kesulitan-kesulitan yang dialami oleh para pedagang dalam hal hygiene dan sanitasi makanan. Kemudian solusi-solusi apa saja yang dapat digunakan untuk mengatasi hambatan dan kesulitan tersebut, sehingga hygiene dan sanitasi makanan akan dapat terimplementasikan dengan baik kepada para pedagang.

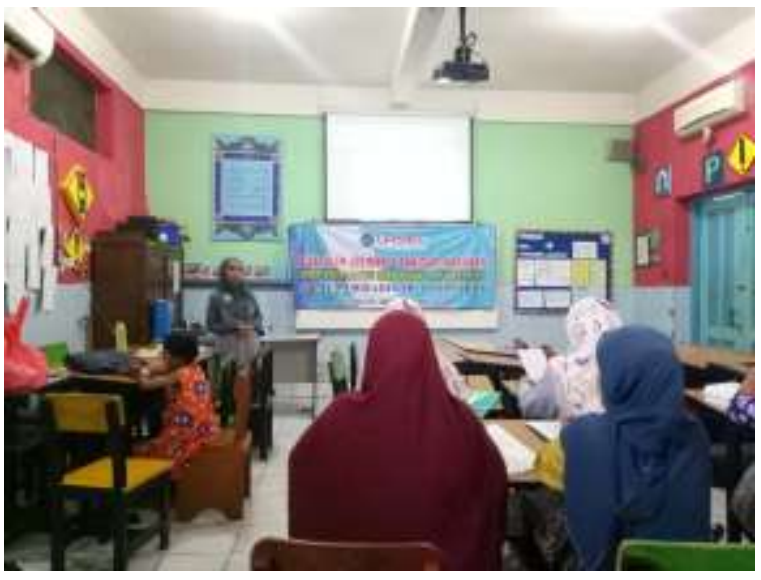

Gambar 3. Forum diskusi hygiene dan sanitasi

Berdasarkan proses pendampingan yang dilakukan dapat diketahui adanya perubahan pengetahuan dan keterampilan para pedagang dalam hal hygiene dan sanitasi makanan. Perubahan tersebut diantaranya: kondisi lingkungan dapur menjadi lebih bersih, pemilihan bahanbahan makanan yang baik, mencuci tangan setelah memegang uang, menggunakan sarung tangan plastik/ sendok/ penjepit makanan dalam mengolah dan menyajikan makanan, mencuci tangan setelah menggaruk kepala atau kaki saat berjualan, dan menggunakan apron/celemek pada saat mengolah makanan di rumah dan berjualan di kantin sekolah (Gambar 3, 4, dan 5). Perubahan-perubahan yang terjadi ini menunjukkan bahwa kegiatan pelatihan dan pendampingan ini dapat dimengerti dan diterapkan dengan baik oleh para pedagang. Pentingnya untuk meningkatkan kualitas hygiene dan sanitasi makanan yang mereka jual sehingga dapat memberikan rasa aman dan kepercayaan konsumennya terhadap makanan yang mereka konsumsi. 




Gambar 4. Perubahan setelah pendampingan pertama di rumah (pedagang $\mathrm{A}$ )

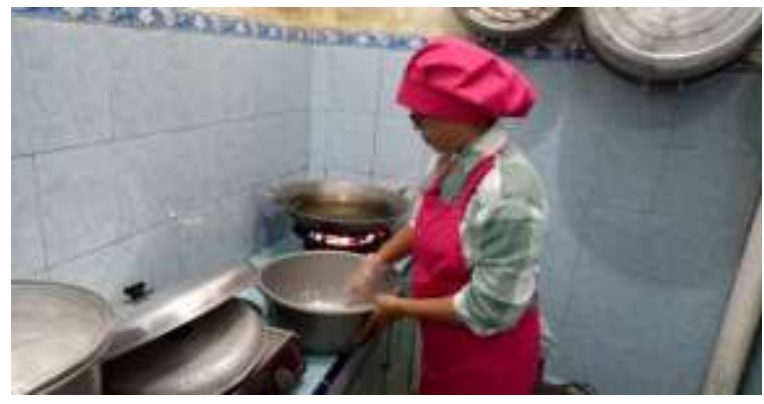

Gambar 5. Perubahan setelah pendampingan pertama di rumah (pedagang $\mathrm{B}$ )

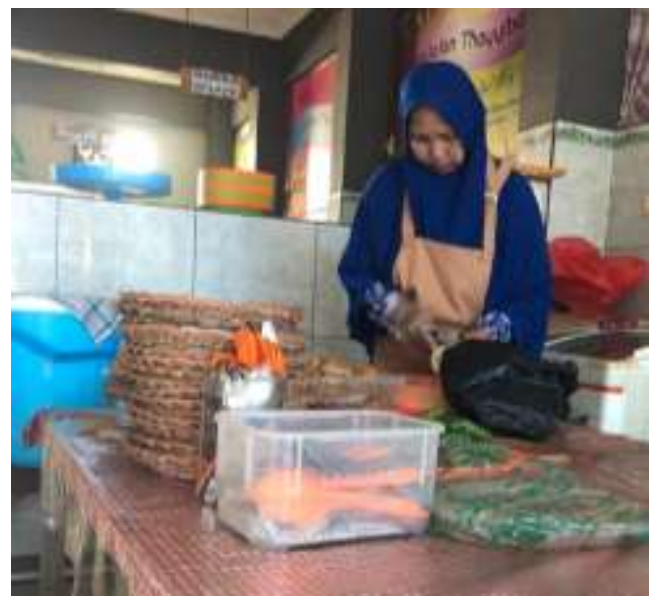

Gambar 6. Perubahan setelah pendampingan pertama di sekolah
Selama proses pendampingan diketahui bahwa sebagian besar pedagang memiliki pengetahuan dan keterampilan yang kurang baik mengenai hygiene dan sanitasi makanan. Mereka mengatakan tidak pernah mendapatkan pelatihan khusus mengenai higiene dan sanitasi makanan sehingga tidak mengetahui dampak negatif yang ditimbulkan akibat pengolahan makanan yang kurang baik. Meskipun mereka sedikit susah mengubah kebiasaan tetapi mereka akan berusaha untuk selalu menjaga kebersihan dalam pengolahan dan penyajian makanan yang dijual.

\section{PENUTUP}

\section{Simpulan}

Pelatihan hygiene dan sanitasi makanan guna meningkatkan pengetahuan dan keterampilan pedagang makanan di kantin SD telah terlaksana dan dapat diterima dengan baik oleh mitra. Edukasi semacam ini sangat penting dilakukan untuk memahamkan pentingnya hygiene dan sanitasi makanan. Sehingga pada kegiatan ini dapat disimpulkan:

1. Meningkatnya pengetahuan dan keterampilan para pedagang makanan di kantin SD tentang hygiene dan sanitasi makanan.

2. Meningkatnya keterampilan para pedagang makanan di kantin SD mengenai hygiene dan sanitasi makanan baik dalam hal pengolahan maupun dalam penyajian makanan.

\section{Saran}

Berdasarkan kegiatan pelatihan yang telah dilakukan, terdapat hal-hal yang dapat dipertimbangkan:

1. Hendaknya bagi para pedagang makanan untuk selalu menerapkan hygiene dan 
sanitasi dalam pengolahan dan penyajian makanan yang dijual.

\section{Ucapan Terima Kasih}

Terima kasih kami ucapkan kepada Universitas Muhammadiyah Sidoarjo, Ketua Lembaga Penelitian Pengabdian dan Pemberdayaan Masyarakat, serta mitra pedagang makanan di kantin SD Muhammadiyah 1 dan 2 Sidoarjo Jawa Timur.

\section{E. DAFTAR PUSTAKA}

Adams. 2003. Dasar-dasar Keamanan Pangan. Jakarta: Buku Kedokteran (EGC).

Departemen Kesehatan RI. 2003. Kumpulan Permenkes Bidang Sanitasi Makanan. PeraturanMenteri Kesehatan Republik Indonesia Tentang Persyaratan Kesehatan Jasaboga.Departemen Kesehatan Republik Indonesia. Jakarta.

Departemen Kesehatan RI. 2006. Keputusan Menteri Kesehatan RI No. 942 Tahun 2003Tentang Persyaratan Higiene Sanitasi Makanan Jajanan. Jakarta.

Departemen Kesehatan RI. 2006. Persyaratan Higiene Sanitasi Rumah Makan dan Jajanan Sekolah. Jakarta.

Hartono, A. 2002. Penyakit Bawaan Makanan: Fokus Pendidikan Kesehatan (Foodborne Disease: a focus for health education), Jakarta. Penerbit Buku Kedokteran EGC.

Ramli, R. 2018. Analisis Pengetahuan Penjamah Makanan Terkait Higiene
Sanitasi Makanan di "Warung Pojok" Umi. Journal of Islamic Nursing. Vol.3 No.1. 20-25.

Winarno, F.G. 2004. Seminar Nasional Proyek Makanan Jajanan IndonesiaNetherlands Street Food Project. Bogor : Institut Pertanian Bogor TNO Division of Nutrition and Food Research Zeist Free University Amsterdam.

WHO. 2005. Penyakit Bawaan Makanan. Jakarta: Buku Kedokteran EGC. 